\title{
SOME REMARKS ON CLIMATE IMPACT ON PREHISTORIC SOCIETIES
}

In some archaeological studies there is a tendency emphasize climate with special strength as a driving force of cultural change in studies covering larger areas over longer periods of time. Migrations are often linked to climate change. In contrast, in small-region studies, researchers are more likely to explore internal factors of change, such as inequality and conflict. On the other hand, in publications postulating the impact of climate on changes in prehistoric societies, it is quite easy to notice the dependence of their authors on a specific theoretical option. For this reason, this article provides an overview of them (classical evolutionism, anthropogeography, culture-historical school, some processualists). For the same reason, selected examples of positive references to climate as a driving force for change and examples where researchers point to other causes are included here. The conclusion stated that even the best documented influence of climatic factors did not affect people directly. As a component of the natural environment that remains outside human culture, climate cannot influence migration or culture change directly. It is part of so called border conditions of cultural and civilizational phenomena, and it may be a necessary condition of cultural change, but never its sufficient condition. Reconstruction of necessary and sufficient conditions requires knowledge of images of the world prevalent in a given society, which involve moral and practical suggestions about how to solve organizational and legal problems in an essential framework of world - view and religion.

Keywords: climate, migrations, culture change, theoretical options, social conflict

\section{INTRODUCTION}

In publications postulating the impact of climate on changes in prehistoric societies, it is quite easy to notice the dependence of their authors on a specific theoretical option. Migrations are often linked to climate change. This shows the popular view about the connection between the great drought in the Central Asian steppes and the expansion of the Huns to the west, and thus the beginning of the Migration Period. For this reason, I will discuss climate and migration together as factors causing significant cultural change within prehistoric societies.

On the other hand, there is a tendency for researchers to emphasize climate with special strength as a driving force of cultural change in studies covering larger areas over longer periods of time.

In contrast, in small-region studies, researchers are more likely to explore internal factors of change, such as inequality and conflict.

2. REVIEW OF THE MAIN THEORIES IN ARCHEOLOGY AND THEIR RELATIONSHIP WITH THE INFLUENCE OF CLIMATE (cf. Kadrow 2020a)

The views of classical evolutionists, who claimed that similar innovations and institutions appeared independently in various places time and time again due to the psychological uniformity of humankind, provoked a reaction: diffusionism. According to the diffusionist model, technologies, religious beliefs, and other cultural ideas spread from one culture to another throughout history, transmitted by migrants (Barth 2005: 11-21). They considered migration as the driving force behind all social and cultural change (Gingrich 2005: 76-93).

The influence of climate on changes in culture was accepted in anthropo-geography based on the principles established by Friedrich Ratzel (1882; 1891), who was a representative of geographical determinism. The works of Ratzel directly shaped the views of many archaeologists (Gradmann 1906; Wahle 1943) and also inspired Herbert Jahnkun (1983) who developed mentioned tendencies and harmonized in them cultural and natural factors (Kadrow 2013, 525, 526).

The 'culture-historical school of archaeology', initiated by Gustaf Kossinna (1911), developed in the same intellectual climate as diffusionism. Kossinna's basic concept of what he called settlement archaeology - equating the distribution of an archaeological culture with the territory of an ethnic community (a tribe or 
a people), and explaining all cultural changes by migration - was universally accepted in Europe in the interwar period, and in the Ostblock countries even after the Second World War.

Culture-historical archaeologists did not carry out original research into social organization. To an even greater extent than classical evolutionists, they drew their knowledge of social groups and structures from historical sources, particularly those relating to ancient Greece, Rome and the Middle East, as well as from ethnological and anthropological research (cf. Redman 1999: 53, 54).

Bronistaw Malinowski - as a functionalist claimed that all elements of a given culture influenced each other, and that every local culture was an integrated complex mechanism helping a human group, which he saw as an organism, to adjust to its environment. Cultural change resulted from interactions with other cultures, mainly via the impact of new ideas and the breakdown of cultural integration caused by the adoption of foreign elements. Functionalists had an organicist view of culture, similar to what was prevalent in classical sociology (Thomas 1999: 434).

Grahame Clark severely criticized culturehistorical archaeology for its focus on diffusion and migration (Clark 1966). He suggested looking for explanation of human behaviour and social change in economics and ecology instead (Thomas 1999, 444), which allows for the inference of the climate impact on culture change.

Julian Steward (neo-evolutionist) viewed technology, economy, and social institutions, which formed the 'cultural core', as the crucial elements of cultures in the process of environmental adaptation. Thus, it allowed for the influence of climate as an important ecological factor on culture change.

Processual archaeologists adopted a neoevolutionist and systemic approaches, using the classical division into 'structure' and 'function' of social organization. One variant of processual archaeology interprets culture as a system consisting of numerous subsystems, e.g. economy, society, religion, and material culture (Clarke 1978: 42-5). The system oscillates around a state of homeostasis, maintaining stable relations with the environment. Change occurs only when the pressure of external factors is so strong that the system, despite its mechanism of self-regulation and its constant striving for equilibrium, can no longer remain stable (Clarke 1978: 52).

Culture is involved in social adaptation to the environment and in permanence of social internal homeostasis. Cultural change takes place when the pool of cultural traits responds flexibly to changing environmental conditions (Binford 1962: 219).

The above-mentioned trends and archaeological theories accept the participation of climate in the mechanism of cultural change or even consider it to be the main factor of such change.

The theoretical trends in archeology that emphasize the internal, socio-economic and cultural sources of change are listed below.

Louis Henry Morgan (1877) founder of social evolutionism, focused on the development of family and property relations, and emphasized the link between social and technological progress.

Social evolutionism had a strong impact on Karl Marx's historical materialism. The two theories shared the notion of a unilinear, jumping, and progressive development of humankind (Szacki 2007: 219-23).

Marx based his reconstruction of human history on the concept of several different modes of production, each characterized by a specific level of productive forces and by specific relations of production. In his theory, productive forces labour power, production techniques, technologies and knowledge - determine the extent to which natural resources and processes taking place in nature can be used, while the relations of production are social mechanisms and institutions involving property, ways of controlling the labour force, and rules governing the distribution of the surplus produced (Habermas 1976: 152$4)$. The interdependent development of productive forces and relations of production gives rise to a finite number of evolutionary stages with a similar structure.

Man Makes Himself (Childe 1936) was a turning point in Childe's research, as it clearly outlined his Marxist inspirations. He also distanced himself from the tendency to explain various prehistoric phenomena with migration.

Neo-Marxism objects to using the concept of classes when analysing pre-industrial societies (Godelier 1977). In exploring 'simple communities', the concept of the family mode of production was suggested instead (e.g. Meillassoux 1981). Even simple communities, however, are perceived as consisting of two contradictory parts: base and superstructure. The contradiction between the base (the family mode of production) and the superstructure (ideology) then leads to social and cultural change (Parkin 2005: 219-22).

In other variants of Neo-Marxism social and cultural change is seen as resulting from various influences (also symbolic ones; Kristiansen and Larsson 2005) exerted by central areas (on a global scale, mostly the Middle East) on peripheries (e.g. Kristiansen 1987; Frank 1993; Sherratt 1993). 
Rejecting the mechanistic and organicist model of society and its culture, post-processual archaeology drew mainly on structuralism (Thomas 1999: 455-9) and then on hermeneutics (pp. 60-463), as shown by its interest in meaning and by the conviction that the outside world is construed and processed in the human mind rather than perceived objectively. The outside world, therefore, is received in many different ways, depending on culturally determined world-views (Gadamer 1975). How we see and explain it results from our position in the world. Following Anthony Giddens and his theory of structuration (Giddens 1984), post-processual archaeology questions the sense of exploring social structures.

The transition from processual archaeology to post-processual archaeology is accompanied by the transfer of interest in inequalities, hierarchies, and social structures to heterarchies and social institutions like families, lineages, and kinship relations, and to the exploration of social equality (cf. Chapman et al. 2006; Kienlin 2012).

\section{SOME EXAMPLES}

a. Case of Lesser Poland in the $4^{\text {th }}$ Millennium BC (Kruk 1973).

In the light of the well-known model developed by Janusz Kruk (e.g. Kruk 1973; 1993) deforestation processes were provoked and then maintained by the use of extensive slash-andburn cultivation, the new basic and regular agricultural technique. The mentioned technique was practiced by Funnel Beaker culture (= TRB) populations not only in SE part of Poland but also almost on the whole Central European Lowland. It was used in territories covered with 'dry' woodlands, which became at the same time the major economically exploited zone. Simultaneously agriculture had to lose its former 'valleylike' garden-type character (Kruk 1993, 11-14).

Kruk's approach is based on the assumption of systemic mutual relations between natural environment, subsistence and the settlement system (Kruk 1973, 190-225). In Kruk's model, slash-and-bur' cultivation - being a part of the new socio-cultural complex of phenomena, known as TRB - operated as a first and most important agent, generating environmental changes (deforestation) and then causing a sequence of further socio-cultural alterations (Baden-like TRB, Corded Ware culture). There is only one contradiction-like problem in this model. Environmental changes, visible also in geological and malacological analyses in the deposits of Western part of Lesser Poland, started from the very beginnings of the $4^{\text {th }}$ Millennium BC
(3900/3800 BC; cf. Kruk et al. 1996, 26, 100), when the intensive settlement of SE group of TRB populations not earlier than at $3700 \mathrm{BC}$ (Kruk et al. 2018). So, an effect seems to be earlier than its effective cause in this model.

Recent palaeogeographical investigations show that various Central and East European river valleys reacted simultaneously to the Late Glacial and Holocene phases. Several increases in fluvial activities conditioned by climatic changes can be noticed (Kalicki 2006). For my considerations the most interesting is one period of increasing fluvial activities, i.e. at the turn of Atlantic and Sub-Boreal periods. In the Vistula valley near Cracow this period is dated to ca. 4500-3600 BC (Kalicki 2006, 292, Fig. 82). It corresponds to the time of later phases of the local Polgar-like culture groups and to the Lublin-Volhynia culture evolution and to the period of the first penetrations of TRB small groups in Lesser Poland. Similar simultaneous sequences of changes are recorded in Byelorussia and on other territories of Europe. They were not disturbed by the various degree of anthropogenic impact (degree of Neolithization; cf. Kalicki 2006, 301). Therefore, it points to the climatic determinations of these fluctuations (including deforestation) and - at the same time - to the domination of 'natural' agents in environmental changes. Human impact on the evolution of river valleys was limited to the indirect intensification of natural processes (Kadrow 2011).

The reconstructed sequence of global climatic changes and their environmental effects (Kalicki 2006, 292) testifies their 'possible' influence on the subsistence strategies. It means that effects of natural climatic changes created only conditions for changes in economy and did not provoke them indispensably and directly. Changes in subsistence strategies, following the environmental ones, are recorded only in few cases (e.g. in some parts of loess uplands of Lesser Poland). In other cases, there was no response of Neolithic communities on these fluctuations (Kadrow 2011), like in the case of Byelorussia, or NE regions of Polish Lowlands.

b. Climatic crisis in Dobruja at the end of $5^{\text {th }}$ millennium BC (Todorova 2002).

"Um 4200 BC (...) alle Steppen - und Semisteppenbereiche im Norden der Balkaninsel (...) waren von der Umweltkrise betroffen (...). In der wasserarmen Steppen der Dobrudscha haben die hohe Temperaturen ohne Zweifel anhaltende Dürren und Hungersnöte ausgelöst. Heute, da diese geoklimatischen Vorgänge bekannt un genauer dateirt dind, kann man, von den Ge- 
danken der Steppeninvasionen abkommend, die ökologische Krise am Höhepunkt des Klimaoptimums als für den Untergang der kupferzeitlichen Kulturen im Nordosten der Balkanhalbinsel verantwortlich bezeichnen (Todorova 2002, 22).

c. Beginning of the Eneolithic in the Steppes of Eastern Europe (Kotova 2005).

"Studying of natural-climatic changes and cultural situation in the steppes of Eastern Europe has shown that the first Eneolithic Sredny Stog culture was formed in the Kalmius and Don interfluve at the beginning of climate aridity about 6400 BP (5350 BC) on the basis of traditions of the population of the Surskaya and late Neolithic Lower Don cultures. About 6300 BP (...) the climate aridity, probably, has forced to migrate a part of the early Sredy Stog population in the northern steppe areas between the Don and Volga that served as the basis for the beginning of emergence of the Khvalinsk Eneolithic culture" (Kotova 2005, 36).

d. Sintashta and origins of Mycenaenian culture (Bátora 2006).

Jozef Bátora's study of population shifts from the territory of the Sintashta culture to Central Europe is another interesting contribution to the debate about climatic influences on migrations (Bátora 2006, 188-192, 301-303). It suggests that fortified settlements built within the cultural complexes of Mad'arovce-Věteřov-Böheimkirchen and Otomany-Füzesabony at the end of the Early Bronze Age, as well as proto-urban settlements in Košice-Barca and Spišský Štvrtok, resulted from cultural influences traceable to the Eurasian part of Russia between the Volga and the Transuralian region, and from Mycenaean influences (Bátora 2006, 302; cf. the same opinion of Lichardus, Vladár 1996). In Bátora's view, complexes from the early Mycenaean culture were similar to complexes of the Sintashta culture, with the latter probably older than the former. The Sintashta culture, then, would have been a prototype for many cultural phenomena in Mycenae (Bátora 2006, 302).

In Eastern Europe and Eurasia in 1700$1300 \mathrm{BC}$, there was a relatively short humid climatic interval, related to the transgression of the Caspian Sea (cf. also Kremenetski 2003: 11; Kalicki 2006: 291 - 295), which led to an increase in population and in stabilisation of settlement in the Sintashta, Abashevo and Mnogovalikovaya cultures. Those changes may have caused population shifts and, consequently, more intense cultural contacts. Bátora notes that, as it is widely known, nomad populations tended to cover great distances in relatively short time; therefore, the spread of certain civilizational achievements was not necessarily multistage and prolonged (Bátora 2006: 302). The role of the Mnogovalikovaya culture as an intermediary in contacts between Eurasia and Central Europe is considered as proven.

Bátora's hypothesis, containing some internal contradictions, has a number of quite surprising consequences. If an increase in climatic humidity enhanced the stabilization of settlement, why did it also force those stably settled people to migrate? Paradoxically, one must deduce from chronological data that even before the increased humidity (starting in approx. $1700 \mathrm{BC}$ ) began to affect people and their environment, it had already caused considerable migration, which resulted in the emergence of the Mycenaean culture (whose beginnings have been dated to approx. $1800 \mathrm{BC}$ ) and the cultural complexes of Mad'arovce-Vĕteřov-Böheimkirchen and Otomany-Füzesabony.

e. Demography and climate in Late Eneolithic Ukraine, Moldova, and Romania (Harper 2017).

Tom Harper (2017) during a multifaceted analysis attempted to correlate macro-scale climate dynamics with anomalies in local and regional archaeological data sets. He reconstructed temperature, precipitation, and growing degree-day trends in Ukraine, Moldova, and Romania from a set of 20 pollen cores in order to explicate the regional impact of the 6.0-5.0 ka BP rapid climate change interval observed in the GISP2 K+ glacio-chemical sequence.

He states that "in the overall population history of the Neo-Eneolithic, the Tripolye giantsettlements (at 100-320 ha each) stand in stark contrast to the vast majority of systems based on local clusters of small and medium-sized sites, with median settlement size fluctuating between 0.5 and 4 ha. Their typological affinities, short period of habitation, and formation during a time of climatic degradation suggests that the giant settlements were more a migratory reaction to events in the Cucuteni-Tripolye "core" area (Diachenko, Menotti 2012) than an endogenous development" (Harper 2017).

According to Diachenko and Menotti (2012) "the major population growth beginning ca. $4100 \mathrm{BC}$ is almost entirely influenced by conditions in Romania and Moldova. The phenomenon of sudden population agglomeration in Central Ukraine during Tripolye B2 and C1 is consistent with recurrent, short-lived "false urbanization" of recent migrant populations within single site" (Harper 2017). 
f. The concept of the 'stage of reduction and concentration of settlements' in Neolithic studies: demography, settlements and social conflict (Kadrow 2020b).

In recent times there is increasing evidence for global climatic changes, contrary to the opinion of Janusz Kruk expressed more than 40 years ago (Kruk 1973). Archaeologists used to look for correlations between settlement and demographic changes and climate fluctuations. For example, the following dependency is postulated among climate and LBK-populations: periods of decreased or irregularly spaced rainfall are contemporaneous to periods of population decline, while periods of increased rainfall may have favoured population growth (Gronenborn et al. 2014).

However, in the cases of microregions of Ostonki, Bronocie and Iwanowice (Kadrow $2020 b)$, the chronology of social crises does not correlate exactly with either the periods of wetting and cooling of the climate, or with drier and warmer periods, readable throughout the European continent (acc. to Kremenetski 2003; Kalicki 2006). More importantly, these crises did not cover larger territories. They are legible only in some settlement centres, while in others the continuation of old development trends is observed. Moreover, these changes are registered in various geographical, environment, cultural and chronological contexts (Kadrow 2020b).

The discussed cases indicate that the stage of reduction and concentration of settlements in their evolution occurs only in cases of settlements which functioned as central places. The largest settlements in their own (micro-) regions (cf. Ostonki: Grygiel 2008, 7-9, 475-476, Fig. 1, 401; Bronocice: Milisauskas, Kruk 1984; Diachenko et al. 2016. Fig. 4; Iwanowice: Kadrow 1995, 33-45, Fig. 11) functioned as such. The existence of a central place is not limited only to one time horizon. The sociocultural structures of the communities which inhabited these settlements were more complex (which does not always mean more hierarchical) in comparison with other communities in the region.

The transition from the stage of central places to the stage of reduction and concentration of settlements always happened during the time of maximal demographic development. This transition was provoked by social conflicts. The emergence, development and fall of these sites were not related to climate changes (Kadrow 2020b).

There is a connection between the depth of a crisis and the severity of the social conflict and its effect in the form of cultural change or change in culture (Kadrow 2020b).
The correlation of the process generating the stage of reduction and concentration of settlements with population growth, the intensification of ritual practices and signs of the crisis and the resulting depopulation and cultural change has been observed in the Rzeszow Neolithic settlement region in southeastern Poland (Kadrow 2020c). A similar course and character of evolution may also be detected in the socio-cultural process in Okolište in Bosnia (e.g. Arponen et al. 2015; Müller 2016).

\section{CONCLUSIONS}

The above-mentioned examples confirm the relationship between researchers who postulate a significant influence of climate (and accompanying migrations) and a specific theory in archeology. On the other hand, they show the dependence of the interpretation used on the spatial extent and duration of the phenomenon under study. Large-scale changes are explained by climatic impacts, while microregional changes were to depend more often on the influence of internal factors, mainly internal conflicts.

It is also important that even the best documented influence of climatic factors did not affect people directly. As a component of the natural environment that remains outside human culture, climate cannot influence migration or culture change directly (Kadrow 2010). It is part of so called border conditions of cultural and civilizational phenomena, and it may be a necessary condition of cultural change, but never its sufficient condition. It creates conditions to introduce some political and organizational solutions (e.g. it can help make the decision to migrate), but does not bring them about directly (cf. Habermas 1983: 494). Reconstruction of necessary and sufficient conditions requires knowledge of images of the world prevalent in a given society, which involve moral and practical suggestions about how to solve organizational and legal problems in an essential framework of world - view and religion (Habermas 1983: 494).

This thesis may be illustrated with the Biblical exodus of clans of herdsmen from Egypt in the $2^{\text {nd }}$ part of the $2^{\text {nd }}$ millennium BC (Kadrow 2010). Joseph, sold into Egyptian bondage by his jealous brothers (Gen. 37:12 - 28), rose high in the pharaoh's court thanks to his exceptional talents (Gen. 41:37 - 57; 47:13 - 26) and triggered great immigration of herdsmen who had starved in Canaan (Gen. 42:1 - 24; 43:1 - 34). The immigrants believed even then that their stay in Egypt would boost their power and importance, as reflected in God's words to Joseph: "Do not be afraid to go down to Egypt, for I will make you into a great 
nation there" (Gen. 46:3). When dying, Joseph assured his brothers that they would not stay in Egypt for ever and that they would receive what God had earlier promised to the great patriarchs: "I am about to die. But God will surely come to your aid and take you up out of this land to the land he promised on oath to Abraham, Isaac and Jacob" (Gen. 50:24). The exodus from Egypt, therefore, had been planned even before the pharaoh started to make the lives of the families bitter (Ex. 1:11-22). After Joseph's death and then after long oppression, the immigrants found a new leader in Moses, who urged them to leave Egypt and go to the Promised Land (Ex. 3:1 - 15; $6: 2-13)$. He led the migrants out of the country (Ex. 12:37 -42), turning them into a nation with a strong sense of its own identity, mainly due to a code of laws and rituals formulated during their journey to Canaan (e.g. Ex. 20:1 - 17).

The Biblical story of the immigrants leaving Egypt, i.e. their migration from Egypt to Canaan, shows clearly that the decisive (necessary and sufficient) condition of their migration (exodus) was the image of the Promised Land present in their consciousness. The image developed before the external factors (the oppression, plagues, starvation etc.), which functioned only as border (necessary but insufficient) conditions. They were conducive to the decision about leaving Egypt; however, the plan to leave Egypt had been formed much earlier and independently of those external (including climatic) factors (Kadrow 2010).

\section{REFERENCES}

Arponen, V. P. J., Müller, J., Hofmann, R., Furholt, M., Ribeiro, A., Horn, C., and Hintz, M. 2015. Using the Capability Approach to Conceptualise Inequality in Archaeology: the Case of the Late Neolithic Bosnian Site Okolinte c. 5200-4600 BCE. Journal of Archaeological Methods and Theory 23: 541-560.

Barth, F. 2005. Britain and the Commonwealth. In F. Barth, A. Gingrich, R. Parkin, and S. Silverman, One Discipline, Four Ways: British, German, French and American Anthropology, 3-57. Chicago: Chicago University Press.

Bátora, J. 2006. Štúdie ku komunikácii medzi Strednou a Východnou Európou v dobe bronzovej. Bratislava.

Binford, L. R. 1962. Archaeology as anthropology. American Antiquity 28: 217-225.

Chapman, J., Higham, T., Slavchev, V., Gaydarska, B., and Honc,N. 2006. The social context of theemergence, developmentandabandonment oftheVarnacemetery,Bulgaria.European JournalofArchaeology9(2-3):159-183.

Childe, V. G. 1936. Man Makes Himself. London: Watts.

Clark, J. G. 1966. The invasion hypothesis in British archaeology. Antiquity 40: 172-189.

Clarke, D. 1978. Analytical Archaeology, 2nd edn. London: Methuen.

Diachenko, A., Kruk, J., and Milisauskas, S. 2016. What does the bell-distribution hide? Spatial behavior and demographis development of the Funnel Beaker Culture populations in Bronocice region, Poland. Sprawozdania Archeologiczne 68: 25-38.

Diachenko, A., Menotti, F. 2012. The gravity model: monitoring the formation and development of hte Tripolye culture giant-settlements in Ukraine. Journal of Archaeological Science 39(4): 2810-2817.

Frank, A. G. 1993. Bronze Age world system cycles. Current Anthropology 34: 383-429.

Gadamer, H.-G. 1975. Wahrheit und Methode. Grundzüge einer philosophischen Hermeneutik. Tübingen: J. C. B. Mohr.

Giddens, A. 1984. The Constitution of Society. Outline of the Theory of Structuration. Oxford: Blackwell.

Gingrich, A. 2005. The German-speaking countries. In F. Barth, A. Gingrich, R. Parkin, and S. Silverman, One Discipline, Four Ways: British, German, French and American Anthropology, 61-156. Chicago: Chicago University Press.

Godelier, M. 1977. Perspectives in Marxist Anthropology. Cambridge: Cambridge University Press.

Gradmann, R. 1906. Beziehungen zwischen Pflanzengeeographie und Siedlungdgeschichte. Geographische Zeitschrift 12, 305-325.

Gronenborn, D., Strien, H.-C., Dietrich, S., and Sirocko, F. 2014. 'Adaptive cycles' and climate fluctuations: a case study from Linear Pottery Culture in western Central Europe. Journal of Archaeological Science 51: 73-83.

Grygiel, R. 2008. The Neolithic and Early Bronze Age in the Brześć Kujawski and Ostonki Region 2(1-3). Middle Neolithic. Brześć Kujawski Group of the Lengyel Culture. Łodź:

Fundacja Badań Archeologicznych Imienia Profesora Konrada Jażdżewskiego, Muzeum Archeologiczne i Etnograficzne $w$ Łodzi.

Habermas, J. 1976. Zur Rekonstruktion des Historischen Materialismus. Frankfurt am Main: Suhrkamp. 
Habermas, J. 1983. Teoria i praktyka. Warszawa: PIW.

Harper, T. 2017. Demography and climate in Late Eneolithic Ukraine, Moldova, and Romania: multiproxy evidence and pollen-based regional corroboration. Journal of Archaeological Science: Reports 23: 973-982.

Jahnkun, H. 1983. Wprowadzenie do archeologii osadnictwa. Warszawa: MKiSz.

Kadrow, S. 1995. Gospodarka i spoteczeństwo. Wczesny okres epoki brązu w Matopolsce, Kraków: IAE PAN.

Kadrow, S. 2010. Examples of Migrations in the Early Phases of the Metal Ages from a Contemporary Sociological Perspective, In K. Dzięgielewski, M. S. Przybyła, A. Gawlik (eds.), Migration in Bronze and Early Iron Age Europe (= Prace Archeologiczne. Studia 63). Kraków 2010, 47-61.

Kadrow, S. 2011. Global Climatic Changes and Culture Change in the Light of More Recent Sociological Concepts - the Mid of $4^{\text {th }}$ Millennium BC in SE Poland. In I. Hildebrandt-Radke, J. Czebreszuk, W. Dörfler, J. Müller (eds.), Anthropogenic Pressure in the Neolithic and Bronze Age in the Central European Lowlands (= Studien zur Archäologie in Ostmitteleuropa 8). Poznań-Bonn: Habelt, 161-171.

Kadrow, S. 2013. Regional research in archaeology in the light of selected traditions of geographical studies. In Kadrow S., Wtodarczak P. (eds.), Environment and subsistence - forty years after Janusz Kruk's „Settlement studies..." (= Studien zur Archäologie in Ostmitteleuropa 11). Rzeszów, Bonn 2013: Institute of Archaeology, Rzeszów University \& Verlag Dr. Rudolf Habelt GmbH, 525-531.

Kadrow, S. 2020a. Social Organization and Change. In A. Gardner, M. Lake, and U. Sommer (eds.), The Oxford Handbook of Archaeological Theory. Oxford: Oxford University Press 2020, 1-22.

Kadrow, S. 2020b. The concept of the 'stage of reduction and concentration of settlements' in Neolithic studies: demography, settlements and social conflict. Documenta Praehistorica 47, 232-244.

Kadrow, S. 2020c. Innovations in ceramic technology in the context of culture change north of the Carpathians at the turn of the $6^{\text {th }}$ and $5^{\text {th }}$ millennia BCE. In Furholt, M., Spataro, M. (eds.). Detecting and explaining technological innovation in prehistory (= Scales of transformation 8). Leiden: Sidestone Press 2020, 85-105.

Kalicki, T. 2006. Zapis zmian klimatu oraz dziatalności cztowieka i ich rola w holoceńskiej ewolucji dolin środkowoeuropejskich. Warszawa.

Kienlin, T. L. 2012. Beyond elites: an introduction. In T. L. Kienlin and A. Zimmermann (eds), Beyond Elites: Alternatives to Hierarchical Systems in Modelling Social Formations, 15-32. Bonn: Rudolf Habelt.

Kossinna, G. 1911. Die Herkunft der Germanen, zur Methode der Siedlungsarchäologie. Würzburg: Kabitzsch.

Kotova, N. S. 2005. Beginning of the Eneolithic in the Steppes of Eastern Europe. Sprawozdania Archeologiczne 57, 9-51.

Kremenetski, K. V. 2003. Steppe and Forest-steppe Belt of Eurasia: Holocene Environmental History. In M. Levine, C. Renfrew, and K. Boyle (eds.), Prehistoric steppe adaptation and the horse. McDonald Institute Monographs. Cambridge University Press. Cambridge: 11-27.

Kristiansen, K. 1987. Centre and periphery in Bronze Age Scandinavia. In M. Rowlands, M. Larsen, and K. Kristiansen (eds), Centre and Periphery in the Ancient World. Cambridge: Cambridge University Press, 74-85.

Kruk, J. 1973. Studia nad neolitem wyżyn lessowych. Kraków.

Kruk, J. 1993. Rozwój spoteczno-gospodarczy i zmiany środowiska przyrodniczego wyżyn lessowych w neolicie (4800-1800 bc). Sprawozdania Archeologiczne 44, 7-17.

Kruk, J., Milisauskas S. 1990. Radiocarbon Dating of Neolithic Assemblages from Bronocice. Przeglad Archeologiczny 37, 195-228.

Kruk, J., Milisauskas, S., Alexandrowicz, S. W., Śnieszko, Z. 1996. Osadnictwo i zmiany środowiska naturalnego wyżyn lessowych. Studium archeologiczne i paleogeograficzne nad neolitem w dorzeczu Nidzicy. Kraków.

Kruk, J., Milisauskas, S., Wtodarczak, P. 2018. Real time. Radiocarbon Dates and Bayesian Analysis of the Neolithic Settlement at Bronocice. Fourth Millennium BC. Kraków: IAE PAN.

Lichardus, J., Vladár, J. 1996. Karpatenbecken - Sintašta - Mykene. Ein Beitrag zur Definition der Bronzezeit als historischer Epoche. Slovenská Archeológia 44, 25-93.

Meillassoux, C. 1981. Maidens, Meal, and Money: Capitalism and the Domestic Community. Cambridge: Cambridge University Press.

Milisauskas, S., Kruk, J. 1984. Settlement organization and the appearance of low level hierarchical societies During the neolithic in the Bronocice Microregion, Southeatsrn Poland. Germania 62: 1-29.

Morgan, L. H. 1877. Ancient Society, or, Researches in the Lines of Human Progress from Savagery, through Barbarism to Civilization. New York: World Publishing.

Muller, J. 2016. From the Neolithic to the Iron Age - Demography and Social Agglomeration: The development of Centralized Control? In M. Fernandez-Gotz, D. Krausse (eds.), Eurasia at the Dawn of History: Urbanization and Social Change. Cambridge University Press. Cambridge: 106-124.

Parkin, R. 2005. The French-speaking countries. In F. Barth, A. Gingrich, R. Parkin, and S. Silverman, One Discipline, Four Ways: British, German, French and American Anthropology, 157-256. Chicago: Chicago University Press.

Ratzel, F. 1992. Anthropogeographie. Die geographische Verbreitung der Menschen 1. Stuttgart: Verlag von J. Engelhorn.

Ratzel, F. 1891. Anthropogeographie. Die geographische Verbreitung der Menschen 2. Stuttgart: Verlag von J. Engelhorn.

Redman, C. L. 1999. The development of archaeological theory: explaining the past. In G. Barker (ed.), A Companion Encyclopedia of Archaeology, 48-80. London: Routledge. 
Sherratt, A. 1993. What would a Bronze-Age world system look like? Relations between temperate Europe and the Mediterranean in later prehistory. Journal of European Archaeology 1(2): 1-58.

Szacki, J. 2007. Historia myśli socjologicznej. Wydanie nowe. Warszawa: Państwowe Wydawnictwo Naukowe. Thomas, J. 1999. Culture and identity. In G. Barker (ed.), Companion Encyclopedia of Archaeology, 431-46. London: Routledge.

Todorova, H. 2002. Die geographische Lage der Gräberfelder. Paläoklima, Strandverschiebungen und Umwelt der Dobrudscha im 6.-4. Jahrtausend v.Chr. In H. Todorova (ed.), Durankulak, Band II. Die prähstorischen Gräberfelder von Durankulak. Teil 1. Sofia, 17-23.

Wahle, E. 1952. Deutsche Vorzeit. Basel: B. Schwabe.

Кадров С.

Інститут археології, Ряшівський університет (Ряшів, Польща)

\section{ДЕЯКІ ЗАУВАЖЕННЯ ЩОДО ВПЛИВУ КЛІМАТУ НА ПЕРВІСНІ СУСПІЛЬСТВА}

У деяких археологічних дослідженнях, що стосуються вивчення значних територій і тривалих хронологічних періодів, спостерігається тенденція надавати кліматичним змінам особливої уваги як рушійній силі культурних трансформацій. Міграції також часто пов'язуються зі зміною клімату. Натомість, у регіональних дослідженнях, дослідники частіше виявляють внутрішні фактори змін, такі як нерівність та конфлікти.

3 іншого боку, у публікаціях, що постулюють вирішальну роль кліматичних змін на процеси трансформації в первісних суспільствах, досить легко помітити залежність їх авторів від конкретної теоретичної концепції. 3 цієї причини в цій статті наводиться їх огляд (класичний еволюціонізм, антропогеографія, культурно-історична школа, деякі процесуалісти). 3 тієї ж причини сюди включено як вибрані приклади, де клімат виступає рушієм суспільних змін, так і приклади, в яких дослідники вказують інші чинники. Вищезазначені приклади підтверджують зв'язок дослідників, які постулюють вирішальний вплив клімату з конкретною теорією в археології. 3 іншого боку, вони показують залежність інтерпретації, від міри простору та тривалості явища, що вивчається.

У висновку зазначається, що навіть найкраще задокументований вплив кліматичних факторів не впливав безпосередньо на людей. Як складова природного середовища, що залишається поза людською культурою, клімат не може впливати безпосередньо на міграцію чи культурну трансформацію. Він $є$ частиною так званих прикордонних умов культурних та цивілізаційних явищ, і може виступати необхідною умовою культурних змін, але ніколи не $є$ достатньою.

Реконструкція необхідних і достатніх умов суспільних змін потребує знання образів світу, поширених у певному суспільстві, які включають моральні та практичні варіанти вирішення організаційних і правових проблем у рамках таких важливих сфер як світогляд та релігія.

Ключові слова: клімат, міграції, зміна культури, теоретичні концепції, соціальний конфлікт 